\title{
Review
}

\section{Hydropower Generation in Malaysia: A Review and Some Notes}

\author{
Chee Wah Yap ${ }^{1}$, Chee Kong Yap ${ }^{2 *}$ (1) \\ ${ }^{1}$ MES SOLUTIONS, 22C-1, Jalan BK 5A/2A, Bandar Kinrara, 47100 Puchong, Selangor, Malaysia \\ ${ }^{2}$ Department of Biology, Faculty of Science, Universiti Putra Malaysia, 43400 UPM Serdang, Selangor, Malaysia \\ Email: yapckong@hotmail.com
}

Received: 2 August 2021; Revised: 31 August 2021; Accepted: 10 September 2021

\begin{abstract}
The objective of this paper was to discuss the future potential of Hydropower Generation (HG) in Malaysia based on available publications published between 1970 and 2021 in the Scopus database (12 papers) and non-Scopus (3 papers). Out of the 15 papers reviewed, it was found that $73 \%$ of papers studied and discussed the economic aspect of the HG in Malaysia, while $27-47 \%$ studied and discussed the social and environmental aspects although some could merge with the economic factor. This paper indicated the economic aspect as primary importance in the hydropower studies and construction in their planning processes until full implementation of this Renewable Energy (RE) in Malaysia. This analysis shows that Large (> 10 MW) Hydropower System (HPS) papers only covered $31 \%$ of the 12 papers (discarding the 2 unspecified papers) reviewed in this study, while the rest $(69 \%)$ covered mostly Micro $(<100$ kW) HPS (46\%), followed by Mini $(<1 \mathrm{MW})$, Small $(<10 \mathrm{MW})$, and Pico $(<5 \mathrm{~kW}) \mathrm{HPSs}$. It is almost certain, the Micro HPS or lower capacities of HPS hold the bright future in the reduced costs of energy consumption in Malaysia with special reference to economic factors that would boost the social development the betterment of well-being of the nation.
\end{abstract}

Keywords: renewable energy, hydropower, Malaysia

\section{Introduction}

Malaysia has committed to reducing its contribution of Green House Gas (GHG) emissions to its gross domestic product by $45 \%$ by 2030 [1], [2]. The government established a target of $20 \%$ Renewable Energy (RE) in the energy mix by 2025 in 2018. The government's dedication to implementing RE in the country was evidenced by the progression of policies [3].

To stimulate and develop the use of RE, the Malaysian government is working hard to improve the effectiveness of regulations, RE programs, and incentives. Malaysia has a lot of fossil fuels, but they are quickly depleting [4]. Although $\mathrm{RE}$ is necessary, current RE resources are insufficient. As a result, additional resource exploration should be explored. RE sources have the advantage of being free of GHG emissions and the accompanying global warming effects [5]. Malaysia's government has set an ambitious aim of boosting RE's share of the country's total energy mix. Malaysia now generates roughly $2 \%$ of its energy from renewable sources, compared to the total generation mix, intending to reach a $20 \%$ penetration rate by 2025 [6].

Malaysia has three significant sources of RE: hydropower, biomass, and solar power [4], [7], [8]. According to

Copyright (C2021 Chee Kong Yap, et al.

DOI: https://doi.org/10.37256/est.3120221074

This is an open-access article distributed under a CC BY license

(Creative Commons Attribution 4.0 International License)

https://creativecommons.org/licenses/by/4.0/ 
the National Energy Balance (NEB) report, Malaysia's total installed electricity-producing capacity was 29,973.8 MW in 2014 [9]. In 2014, gross energy generation increased by 2.8\% to 147,480 Gigawatt-Hours (GWh), up from 143,497 GWh in 2013. According to the research, hydropower was the most common RE source, accounting for $83.3 \%$ of all renewable electricity generated and $15.9 \%$ of total electricity output in the country.

Hydropower Generation (HG) is one viable alternative for ensuring continuous energy supply worldwide via RE to fulfill rising energy demand [5], [10]. The global hydropower capacity was 2,819 TWh in 2004 and is expected to expand to 4,903 TWh by 2030 , with an annual growth rate of $1.8 \%$, however its share of global energy supply will remain at 2\% [11]. Hydropower has enormous potential to address energy demand in Southeast Asia, especially Malaysia, due to rapid economic expansion and limited energy supply [12]. With a modern hydro system's efficiency of over $85 \%$, compared to only approximately $50 \%$ for a typical fossil-fuel-based plant [13], [14], hydropower could play a critical role in Malaysia's sustainable and eco-friendly energy mix [15] in the future [16].

Malaysia's natural water resource potential is vast [12]. This is due to the number of streams and rivers coming from Malaysia's highlands, which promise a lot of hydropower potential, ranging from large and mini hydropower to a few micro hydropower plants [17]. Malaysia has 189 rivers with a total length of 57,300 kilometers [4], [18].

Small hydro stations with a capacity of less than $30 \mathrm{MW}$ operate in a liberalized market, which means they are available to any private developer and are primarily subsidized through the Malaysian Sustainable Energy Development Authority's (SEDA) Feed-in Tariff (FiT) system [19]. Therefore, it is postulated that the current trend of HPS in Malaysia is focussed and recommended on the capacity of mini, micro, and pico HPSs.

The objective of this paper is to discuss the future potential of HG in Malaysia based on available publications published between 1970 and 2021 in the literature.

\section{Methodology}

Keywords 'Hydro' and 'Malaysia' were used in this review study to find available publications in the Scopus database between 1970 and 2021, as searched on July 25, 2021. A total of 32 papers were found during the search. However, only 12 abstracts from papers with related keywords, topics, and investigations were chosen. Since some related papers in the Scopus database could be missing, 3 related papers were found from the Google search (NonScopus). All of these 15 papers were further scrutinized and synthesized.

\section{Review findings}

A review of hydropower in Malaysia from 1970-2021 is presented in Table 1. In any environmental management, three major and integrated perspectives are involved. These are the perspectives on the environment, the economy, and society. According to Murni et al. [20], technical, social, economic, and organizational challenges, as well as the policy framework in which they are implemented, must all be considered in the hydropower-related issues. In the twelve papers reviewed, comment on each paper is based on the perspective(s) on which the paper is focused upon.

The classifications of hydropower scheme with different capacities are 'Large (>10MW)', 'Small $(<10 \mathrm{MW})$ ', Mini (<1 MW)', 'Micro (<100 kW)', and 'Pico (<5 kW)' [4], [21]-[24].

Newbery [25] reported the first paper only based on the Scopus database. The article focused on the Batang Padang hydroelectric system in West Malaysia, which is situated in a tropically weathered granite environment. The focus of this paper was on the environment. They established that the cavern will be excavated in the unbroken rock, using bolts, granite, and mesh for permanent support. It was able to assess the site investigation's success during building. Tunneling through residual soil below the water table proved to be a considerable geological challenge. Flow slips resulted, forcing tunnel diversions. 
Table 1. A review of hydropower in Malaysia from 1970-2021

\begin{tabular}{|c|c|c|c|c|}
\hline No. & Location & Major finding(s) & Perspective(s)/HPS potential & Reference \\
\hline 1. & $\begin{array}{l}\text { The Batang Padang HG } \\
\text { system in West Malaysia }\end{array}$ & $\begin{array}{l}\text { Tunneling through residual soil below the water table } \\
\text { proved to be a considerable geological challenge. } \\
\text { Flow slips resulted, forcing tunnel diversions }\end{array}$ & $\begin{array}{c}\text { Environment/Signified the hydropower } \\
\text { potential in West Malaysia. } \\
\text { The capacity of HPS unspecified. }\end{array}$ & {$[25]$} \\
\hline 2. & $\begin{array}{l}\text { HG developments in Bersia } \\
\text { and Kenering, both in Perak’s } \\
\text { northern state }\end{array}$ & $\begin{array}{l}\text { In a hybrid hydro-thermal power development } \\
\text { initiative, this would add } 192 \mathrm{MW} \text { of generating } \\
\text { capacity to the National Electricity Board of } \\
\text { the States of Malaya's electric grid }\end{array}$ & Social-economy/Large HPS & {$[26]$} \\
\hline 3. & $\begin{array}{l}\text { The micro HG projects } \\
\text { at } 41 \text { sites in Peninsular } \\
\text { Malaysia were outlined }\end{array}$ & $\begin{array}{l}\text { Hydrologic methodology, energy planning, } \\
\text { pre-reconnaissance operations, field investigation } \\
\text { processes, field surveys, project layouts, } \\
\text { turbine/generator equipment, cost estimates, } \\
\text { economic analysis, and excess energy usage } \\
\text { were among the topics discussed }\end{array}$ & Environment and economy/Micro HPS & {$[27]$} \\
\hline 4. & $\begin{array}{l}\text { Identification of the micro HG } \\
\text { potential in West Malaysia }\end{array}$ & $\begin{array}{l}\text { A total of } 109 \text { sites were found, with a total micro HG } \\
\text { potential of around } 20.4 \mathrm{MW} \text { (in a total of all } 109 \text { sites) }\end{array}$ & Economy/Micro HPS & [28] \\
\hline 5. & $\begin{array}{l}\text { The } 2400 \text { MW Bakun dam } \\
\text { project in Sarawak }\end{array}$ & $\begin{array}{l}\text { The societal implications of HG development at } \\
\text { the Bakun dam project in Sarawak were } \\
\text { the focus of this study }\end{array}$ & Social and environment/Large HPS & [29] \\
\hline 6. & $\begin{array}{l}\text { The micro HG potential sites } \\
\text { in Malaysia were identified }\end{array}$ & $\begin{array}{l}\text { A total of } 149 \text { sites with a micro-hydro potential of } \\
28.9 \mathrm{MW} \text { (in a total of } 149 \text { sites) were identified }\end{array}$ & Economy/Micro HPS & {$[30]$} \\
\hline 7. & $\begin{array}{l}\text { Two micro HPS projects } \\
\text { in Borneo's highlands }\end{array}$ & $\begin{array}{l}\text { The performance and reliability of micro HPS were } \\
\text { shown to be significantly influenced by the role of } \\
\text { the local management committee and } \\
\text { other members of the local community }\end{array}$ & Social/Micro HPS & {$[20]$} \\
\hline 8. & $\begin{array}{l}\text { The study focused on } \\
\text { small-scale HG's potential } \\
\text { in Malaysia }\end{array}$ & $\begin{array}{l}\text { Malaysia's hydropower resources are projected to be } \\
29,000 \mathrm{MW} \text {, with } 500 \mathrm{MW} \text { coming from small (mini) } \\
\text { hydropower at } 149 \text { sites. However, constraints } \\
\text { included technical, economic, and institutional aspects }\end{array}$ & $\begin{array}{l}\text { Social-economy/Mini HPS } \\
\text { facing many constraints }\end{array}$ & {$[31]$} \\
\hline 9. & $\begin{array}{l}\text { The UTHM ECO-Hydro } \\
\text { Team, in conjunction with } \\
\text { the Johor National Park } \\
\text { Company, began work on a } \\
\text { project to establish a micro- } \\
\text { HG plant near Endau Rompin }\end{array}$ & $\begin{array}{l}\text { The micro HPS technology was used in conjunction } \\
\text { with the diesel generator to create } \\
\text { a hybrid power generation system }\end{array}$ & Economy/Micro HPS & {$[32]$} \\
\hline 10. & $\begin{array}{l}\text { Micro HPS plants in the } \\
\text { east coast region }\end{array}$ & $\begin{array}{c}\text { Humidity and rainfall had a substantial impact } \\
\text { on small HG. These two factors could be } \\
\text { utilized to forecast small HG }\end{array}$ & Environment and economy/Micro HPS & [33] \\
\hline 11. & $\begin{array}{l}\text { Kg. Tual, Raub, Pahang } \\
\text { and Gunung Ledang, } \\
\text { Tangkak, Johor }\end{array}$ & $\begin{array}{c}\text { Using a Pelton or Turgo turbine, the Kg. Tual project } \\
\text { was shown to be capable of producing } 266.99 \mathrm{~kW} \text {. } \\
\text { Because the Gunung Ledang site could only produce } \\
4.75 \mathrm{~kW} \text {, it was a good candidate } \\
\text { for a Kaplan or crossflow turbine }\end{array}$ & $\begin{array}{c}\text { Environmental and economy/Kg. } \\
\text { Tual (Mini HPS) and } \\
\text { Gunung Ledang (Pico HPS) }\end{array}$ & [24] \\
\hline 12. & $\begin{array}{l}\text { Bukit Merah Dam site, } \\
\text { on the Terusan Besar } \\
\text { irrigation canal in the } \\
\text { northern region of Malaysia }\end{array}$ & There was a potential capacity of $2.2 \mathrm{MW}$ & Economy/Small HPS & [34] \\
\hline 13. & $\begin{array}{l}\text { This research established } \\
\text { a methodology for sizing a } \\
\text { hybrid system that uses solar } \\
\text { energy and direct rainfall } \\
\text { for HG to fulfill } \\
\text { the load demand of rural } \\
\text { Malaysian households }\end{array}$ & $\begin{array}{c}\text { It was suggested that an integrated solar/rainfall-based } \\
\text { HPS with robust power control and water storage } \\
\text { would be more beneficial }\end{array}$ & $\begin{array}{l}\text { Environment and economy/Capacity } \\
\text { of HPS unspecified }\end{array}$ & {$[35]$} \\
\hline 14. & $\begin{array}{l}\text { Kenyir Lake catchment } \\
\text { area, which was primarily } \\
\text { comprised of woods and } \\
\text { the large Kenyir Lake }\end{array}$ & $\begin{array}{l}\text { The carbon sink capability in the Kenyir Lake } \\
\text { catchment area was found to be satisfactory, with just a } \\
\text { 17\% drop in sequestration ability. Despite modifications } \\
\text { caused by dam building, the study area's landscape was } \\
\text { assessed to be a densely vegetated area }\end{array}$ & Environment/Large HPS & [36] \\
\hline 15. & Kenyir Lake & $\begin{array}{l}\text { Rising temperatures gave various patterns of demand } \\
\text { because higher temperatures would create higher } \\
\text { cooling demand. Climate change tremendously affected } \\
\text { the energy demand patterns and supply systems }\end{array}$ & Environment/Large HPS & [37] \\
\hline
\end{tabular}

Note: $\mathrm{HG}=$ Hydropower Generation; RE = Renewable Energy; HPS = Hydropower System 
The Bersia and Kenering Hydro-Electric Developments in the Northern State of Perak, West Malaysia, were reported by Bondale [26]. The focus of this research was on the social-economic approach. In a hybrid hydro-thermal power development initiative, this will add $192 \mathrm{MW}$ of generating capacity to the National Electricity Board of the States of Malaya's electric grid. The project, which was set to be completed in 1983 (Bersia) and 1983/84 (Kenering), would fully use the upper Perak river's capacity, as envisioned in the 1966 feasibility study.

Little [27] presented the techniques, assumptions, and criteria used in feasibility assessments for 41 sites in Peninsular Malaysia. The focus of this study was on the environment and the economy. All of the sites had a minor diversion weir and intake structure, a penstock with an access road, a power plant, and a transmission line going to the point of usage. The study's general procedures are discussed, followed by a discussion of key aspects such as hydrologic methodologies, energy planning, pre-reconnaissance activities, field investigation procedures, field surveys, project layouts, turbine/generator equipment, cost estimates, economic analysis, and excess energy utilization.

By identifying micro hydropower potential, Raman et al. [28] focused on the economic standpoint. They presented the findings of reconnaissance surveys conducted to determine West Malaysia's micro hydropower potential. The research used data from the Malaysian Metrological Department and the Malaysian Department of Survey and Mapping. A total of 109 locations with a micro-hydro potential of roughly 20.4 MW (a total of all micro HPS of 109 locations) were found during reconnaissance surveys. However, because most places in West Malaysia are electrified, the energy demand for micro-hydro is insignificant. Despite the escalating cost of power, micro-hydro generation may become a viable alternative RE source in the future.

Mamit [29] focused on the social and environmental viewpoints in his article. At the 2400-MW Bakun dam project in Sarawak, Malaysia, Mamit [29] discussed the societal implications of hydro development. Defining social goals, planning social actions, and analyzing risks are all part of social evaluation. The consequences of hydropower development on boomtowns are well documented, and there is a lot of experience controlling boomtown growth. The Bakun system has downstream negative consequences, such as reduced river water availability during dam impoundment and infrequent flooding. To conduct the social and environmental impact assessments at Bakun, the government is using a new approach that complies with international standards. It was critical to have effective executing bodies, such as the State Planning Unit, the Belaga District Office, and the Steering/Technical Working Committees, as well as public participation in identifying relocation alternatives.

Raman and Hussein [30] focused on the economic angle in their paper. They found potential micro-hydropower sites and reported the findings of a reconnaissance study conducted in Malaysia to locate micro hydropower potential sites. The reconnaissance research used data from the Malaysian Metrological Department and the Malaysian Department of Survey and Mapping. As a consequence of the reconnaissance research, 149 locations with a microhydro potential of $28.9 \mathrm{MW}$ (a total of all micro HPS of 149 locations) were identified. However, because much of Malaysia is electrified, the energy demand for micro hydro was found to be insignificant. Despite the escalating cost of power, micro-hydro generation may become a viable alternative RE source in the future.

Murni et al. [20] concentrated on the social aspect of the study. They presented the results of a stakeholder survey for two micro-hydro system (MHS) projects in Borneo's highlands. The survey outcomes showed that to assure project success, essential critical variables must be given special attention. The role of the local micro-hydro management committee and other members of the local community were found to have a significant impact on the MHSs' performance and reliability. Village culture and the national energy policy context in which the initiatives are conceived and administered were also found to have an impact on project success.

Yah et al. [31] concentrated on economic and social issues. They discussed the possibilities of small-scale hydropower in Malaysia, as well as the existing state of low-head hydropower and rural electricity. Although hydropower technologies are preferred for energy generation in Malaysia, they have yet to be completely utilized because of technical, economic, and institutional obstacles.

Yusop et al. [32] concentrated on the economic side of things. On a project to establish a micro-hydropower plant at Endau Rompin, the UTHM ECO-Hydro Team partnered with the National Education Research Center Johor National Park Corporation. The micro-hydro system works in tandem with the diesel generator to create a hybrid power generating system that powered the houses in the vicinity

Hamid et al. [33] focused on the economy and the environment. Small hydropower is the most cost-effective energy technique for rural areas, thus they focused on it. Apart from the technology itself, mini hydropower is highly 
dependent on weather variables such as temperature, rainfall, humidity, and others. In their study, they took into account environmental factors that influence energy output by micro hydropower plants on the east coast. They collected data from the Malaysian Meteorological Department from January 2010 to December 2015. They concluded that humidity and rainfall had a major impact on small hydropower output. They also suggested that machine learning methods such as artificial neural networks, and support vector machines, be utilized to forecast micro hydropower plant energy production.

Musa et al. [24] investigated the use of HPS in two distant off-grid locations in Malaysia: Kg. Tual, an Orang Asli community near Raub (Pahang), and Gunung Ledang, Tangkak (Johor). They measured the stream flow rate and head from the intended water intake to the proposed powerhouse location to determine the best type of small-scale hydropower system turbine that might be used at the sites. They found that $\mathrm{Kg}$. Tual scheme was found fit for creating $266.99 \mathrm{~kW}$ with an expense of energy of RM0.017 per kWh by utilizing a Pelton or Turgo turbine. Nonetheless, the Gunung Ledang site was reasonable for utilizing a Kaplan or crossflow turbine as it was capable of delivering just 4.75 $\mathrm{kW}$ for RM0.159 per kWh.

Roslan et al. [34] led a practicality investigation of the technical viability of power generation from a medium hydropower expected site, the Bukit Merah Dam site, on the Terusan Besar water system channel in the northern district of Malaysia. They found that there was a possible limit of $2.2 \mathrm{MW}$ and a yearly energy age limit of 7,028.47 MWh at a turbine top effectiveness of $92.8 \%$ at a design flow of $19.23 \mathrm{~m}^{3} / \mathrm{s}$ utilizing a Kaplan turbine.

Bhayo et al. [35] concentrated on the economy and the environment. They developed a method for determining the appropriate size of a hybrid system that employs solar energy and direct rainfall to meet the load requirement of rural Malaysian households. When Photovoltaics (PV) output is insufficient to satisfy load demand, rain from the catchment area is used to create electricity. It was suggested that an integrated solar/rainfall-based hydro system with robust power control and water storage would be more beneficial.

Dullah et al. [36] concentrated on the environment. They calculated the loss of forest carbon owing to these operations during 37 years, from 1972 to 2019. The Kenyir Lake catchment area, which was mostly made up of woods, and the massive Kenyir Lake, served as the research area. Remote sensing datasets were used in this study. According to the findings, a carbon sequestration scenario in the Kenyir Lake catchment area reveals that the carbon sink's potential in the research area was adequate, with only a $17 \%$ reduction in sequestration capabilities.

Azman et al. [37] studied the severity of rainfall trends and also predict the fluctuations of hydropower generation in Kenyir Lake triggered by the variations of climatic factors under selected Representative Concentration Pathways (RCP). The historical daily data of seven rainfall stations for 30 years' period (1988-2017) and global climate model data for RCP2.6, RCP4.5, and RCP8.5 also for 30 years' period (2041-2070) were used. They found that the significant differences were recorded in November and December where an abrupt fall of rainfall distribution was predicted to happen for all RCPs. The results proved that the higher emissions level will give more effect to the climate trend as the previous researcher found that warming will remain beyond 2,100 for all RCP scenarios except RCP2.6. They also concluded that power generation can change accordingly by decreasing streamflow and increasing water temperature, indicating climate change tremendously would affect the energy demand patterns and supply systems.

Seven, four, and eleven of the fifteen publications in Table 1 focused on environmental, social, and economic issues, respectively. This indicated that $73 \%$ of publications examined and addressed the economic element of Malaysian hydropower, whereas $27-47 \%$ studied and discussed the social and environmental aspects, albeit some of these may merge with the economic factor.

From an economic standpoint, hydropower requires a significant initial expenditure, which can be a disincentive to potential investors [38]. However, this must be evaluated against the long-term and operating expenses of hydropower facilities, as well as the fact that no fuel is used in the energy generation process [39]. The implementation hurdles are numerous, including considerable consequences on land use, socio-economics, and the environment, making it unclear whether all of this potential can be fully realized.

From Table 1 again, it can be seen that Large HPS covered 4 papers, Micro HPS covered 6 papers, Mini HPS covered 1 paper, Mini and Pico HPS covered 1 paper, Small HPS covered 1 and unspecified HPS covered 2 papers. This analysis shows that Large HPS papers only covered $31 \%$ of the 12 papers (discarding the 2 unspecified papers) reviewed in this study, while the rest (69\%) covered mostly Micro HPS (46\%), followed by Mini, Small, and Pico HPSs.

Due to cabling cost and topographical limitations, the rural electrification program requires an in-situ application 
which makes the Micro HPS a more favorable decision. This run-of-river scheme is harmless to the ecosystem as no dam is required which has prompted a worldwide multiplication of this hydropower innovation [40] due to increasing awareness concerning river conservation and restoration [41]. This was because the environmental consequences of massive large HPS projects have recently been highlighted as a topic of concern [18].

Likely areas in Malaysia have been recommended for Small and Micro-hydro turbine applications, which are great for the eco-friendly tourist industry [24]. Specifically, the pico hydropower framework (PHPS) offers productive, and practical alternative power sources for remote areas as the development of dams is not needed. Therefore, this has negligible impacts on the climate [42]. PHPS is a RE source that utilizes a little engine or generator that is associated with turbines to create power without depending on any non-RE sources [43].

\section{Concluding remarks}

Out of the 15 studies analyzed, 73\% investigated and addressed the economic element of Malaysian hydropower, while $27-47 \%$ studied and discussed the social and environmental aspects, however, some overlapped with the economic factor. This study emphasized the relevance of the economic factor in hydropower research and construction in their planning procedures till the RE is fully implemented in Malaysia. This analysis shows that Large HPS papers only covered $31 \%$ of the 12 papers (discarding the 2 unspecified papers) reviewed in this study, while the rest $(69 \%)$ covered mostly Micro HPS (46\%), followed by Mini, Small, and Pico HPSs. It is almost likely that the Micro or lower capacities of HPS have a bright future in Malaysia in terms of lowering energy consumption costs, particularly in terms of economic factors that would stimulate social development and improve the nation's well-being.

\section{Acknowledgements}

The authors gratefully acknowledge three anonymous reviewers who provided constructive comments that greatly improved the manuscript.

\section{Author contributions}

CWY and CKY conceptualized, planned the study, prepared the original draft, and edited the manuscript. Both authors have read and approved the final manuscript.

\section{Funding}

This study received no research grant from any sources.

\section{Declarations}

Ethics approval: Not applicable.

Consent to participate: Not applicable.

Consent for publication: Not applicable.

\section{Conflict of interest}

The authors declare no conflict of interest. 


\section{References}

[1] A. X. Y. Mah, W. S. Ho, C. P. C. Bong, M. H. Hassim, P. Y. Liew, U. A. Asli, M. J. Kamaruddin, and N. G. Chemmanggattuvalappil, "Review of hydrogen economy in Malaysia and its way forward," International Journal of Hydrogen Energy, vol. 44, no. 12, pp. 1-15, 2019.

[2] X. L. Lim, W. H. Lam, and R. Hashim, "Feasibility of marine renewable energy to the Feed-in Tari_ system in Malaysia," Renewable and Sustainable Energy Reviews, vol. 49, pp. 708-719, 2015.

[3] A. L. Maulud and H. Saidi, "The Malaysian Fifth Fuel Policy: Re-strategising the Malaysian Renewable Energy Initiatives," Energy Policy, vol. 48, pp. 88-92, 2012.

[4] M. Hossain, A. S. N. Huda, S. Mekhilef, M. Seyedmahmoudian, B. Horan, A. Stojcevski, and M. Ahmed, "A stateof-the-art review of hydropower in Malaysia as renewable energy: Current status and future prospects," Energy Strategy Reviews, vol. 22, pp. 426-437, 2018.

[5] J. O. Petinrin and M. Shaaban, "Renewable energy for continuous energy sustainability in Malaysia," Renewable and Sustainable Energy Reviews, vol. 50, pp. 967-981, 2015.

[6] W. S. W. Abdullah, M. Osman, M. Z. A. Ab Kadir, and R. Verayiah, "The potential and status of renewable energy development in Malaysia," Energies, vol. 12, pp. 2437, 2019.

[7] L. M. Halabi, S. Mekhilef, and M. Hossain, "Performance evaluation of hybrid adaptive neuro-fuzzy inference system models for predicting monthly global solar radiation," Applied Energy, vol. 213, pp. 247-261, 2018.

[8] M. Hossain, S. Mekhilef, and L. Olatomiwa, "Performance evaluation of a stand-alone PVwind-diesel-battery hybrid system feasible for a large resort center in South China Sea, Malaysia," Sustainable Cities and Society, vol. 28, pp. 358-366, 2017.

[9] B. K. Sovacool and L. C. Bulan, "Energy security and hydropower development in Malaysia: the drivers and challenges facing the Sarawak Corridor of Renewable Energy (SCORE)," Renewable Energy, vol. 40, pp. 113-129, 2012.

[10] M. Shaaban and J. O. Petinrin, "Renewable energy potentials in Nigeria: meeting rural energy needs," Renewable and Sustainable Energy Reviews, vol. 29, pp. 72-84, 2014.

[11] H. A. Bada, "Managing the diffusion and adoption of renewable energy technologies in Nigeria," World Renewable Energy Congress, pp. 2642-2649, 2011.

[12] S. W. Tang, J. T. Chen, P. G. Sun, Y. Li, P. Yu, and E. Chen, "Current and future hydropower development in Southeast Asia countries (Malaysia, Indonesia, Thailand and Myanmar)," Energy Policy, vol. 129, pp. 239-249, 2019.

[13] A. Akpınar, "The contribution of hydropower in meeting electric energy needs: the case of Turkey," Renewable Energy, vol. 51, pp. 206-219, 2013.

[14] B. Dursun and C. Gokcol, "The role of hydroelectric power and contribution of small hydropower plants for sustainable development in Turkey," Renewable Energy, vol. 36, pp. 1227-1235, 2011.

[15] I. Yuksel, "Dams and hydropower for sustainable development," Energy Sources, vol. 4, pp. 100-110, 2009.

[16] S. M. C. Fairuz, M. Y. Sulaiman, C. H. Lim, S. Mat, B. Ali, O. Saadatian, M. H. Ruslan, E. Salleh, and K. Sopian, "Long term strategy for electricity generation in Peninsular Malaysia-analysis of cost and carbon footprint using MESSAGE," Energy Policy, vol. 62, pp. 493-502, 2013.

[17] I. Hussein and N. Raman, "Reconnaissance studies of micro hydro potential in Malaysia," In proceedings of the International Conference on Energy and Sustainable Development: Issues and Strategies, ESD 2010, 5598802, 2010.

[18] M. Mohibullah, A. M. Radzi, and M. I. A. Hakim, "Basic design aspects of micro hydro power plant and its potential development in Malaysia," PECon 2004. Proceedings. National Power and Energy Conference, 2004, pp. 220-223.

[19] IHA (International Hydropower Association). Hydropower Status Report, [online document], 2019. Available: https://www.hydroworld.com/content/dam/hydroworld/online-articles/2017/08/2017\%20Hydropower\%20 Status\%20Report-1.pdf [Accessed April 20, 2019].

[20] S. Murni, T. Urmee, J. Whale, J. K. Davis, and D. Harries, “The implementation of micro hydro projects in remote villages on the border of Indonesia and Malaysia: Lessons learnt," In proceedings of the 2014 International Conference and Utility Exhibition on Green Energy for Sustainable Development, ICUE 2014, art. no. 6828956. 2014.

[21] J. Susanto and S. Stamp, "Local installation methods for low head pico-hydropower in the Lao PDR," Renew Energy, vol. 44, pp. 439-447, 2012.

[22] M. R. B. Khan, R. Jidin, J. Pasupuleti, and S. A. Shaaya, "Micro-hydropower potential assessment and generation 
volatility due to seasonal climate," IEEE International Conference on Power and Energy, 2014, pp. 371-376.

[23] A. Gagliano, G. M. Tina, F. Nocera, and F. Patania, "Technical and economic perspective for repowering of micro hydro power plants: a case study of an early xx century power plant," Energy Proc, vol. 62, pp. 512-521, 2014.

[24] M. Musa, J. A. Razak, M. M. Tahir, I. S. Mohamad, and M. N. Othman, "Small scale hydro turbines for sustainable rural electrification program," Journal of Advanced Research in Fluid Mechanics and Thermal Sciences, vol. 49, no. 2, pp. 138-145, 2018.

[25] J. Newbery, "Engineering geology in the investigation and construction of the Batang Padang hydro-electric scheme, Malaysia," Quarterly Journal of Engineering Geology, vol. 3, no. 3, pp. 151-181, 1970.

[26] D. S. Bondale, "Bersia and Kenering hydro electric project, West Malaysia," Canadian Electrical Association, Engineering and Operating Division, Transactions, 1983.

[27] G. E. Little, "Experiences on mini hydro feasibility studies for isolated sites in Alaska and Malaysia," In: Waterpower '83, Int. Conf. on hydro power, conf. proc., (Knoxville, U.S.A.: Sep. 18-21, 1983), Knoxville, U.S.A., Tennessee Valley Auth., 1983, pp. 284-296.

[28] N. Raman, I. Hussein, and K. Palanisamy, “Micro hydro potential in West Malaysia," ICEE 2009-Proceeding 2009 3rd International Conference on Energy and Environment: Advancement Towards Global Sustainability, 2009, pp. 348-359.

[29] J. D. Mamit, “Social impacts of hydro development: Experiences from Bakun, Malaysia," International Journal on Hydropower and Dams, vol. 17, no. 2, pp. 63-65, 2010.

[30] N. Raman, and I. Hussein, "Reconnaissance study to identify micro hydro potential sites in Malaysia," European Journal of Scientific Research, vol. 41, no. 3, pp. 354-372, 2010.

[31] N. F. Yah, A. N. Oumer, and M. S. Idris, "Small scale hydro-power as a source of renewable energy in Malaysia: A review," Renewable and Sustainable Energy Reviews, vol. 72, pp. 228-239, 2017.

[32] A. Yusop, I. Yahaya, G. Kadis, M. Ishak, M. S. Abdullah, M. F. Razak, A. Sidek, and I. R. Abdul, "Hybrid micro-hydro power generation development in Endau Rompin National Park Johor, Malaysia," MATEC Web of Conferences, 2017.

[33] M. F. A. Hamid, N. A. Ramli, and S. N. B. M. Napiah, "Factors affecting mini hydro power production efficiency: A case study in Malaysia," 3rd International Conference on Power Generation Systems and Renewable Energy Technologies, PGSRET 2017, 2018-January, 2018, pp. 85-88.

[34] E. Roslan, S. Suhail, Z. Faiz, A. Afifi, S. Fatihah, R. Zakwan, and S. Abd Halim, "Hydropower potential of agricultural dam in Bukit Merah," International Journal of Recent Technology and Engineering, vol. 8, no. 4, 2019.

[35] B. A. Bhayo, H. H. Al-Kayiem, and S. I. U. Gilani, "A framework for the optimal sizing of hybrid solar pv-batteryhydro system for a rural house in Malaysia," Lecture Notes in Mechanical Engineering, pp. 733-740, 2020.

[36] H. Dullah, M. A. Malek, H. Omar, S. A. Mangi, M. M. Hanafiah, "Assessing changes of carbon stock in dipterocarp forest due to hydro-electric dam construction in Malaysia," Environmental Science and Pollution Research, vol. 28, pp. 44264-44276, 2021.

[37] A. H. Azman, N. N. A. Tukimat, and M. A. Malek, "Climate change impacts on hydropower at Kenyir Lake," Journal of Engineering Science and Technology, vol. 16, no. 2, pp. 1287-1298, 2021.

[38] M. Islam, R. Saidur, N. A. Rahim, and K. H. Solangi, "Renewable energy research in Malaysia," Engineering e-Transaction, vol. 4, no. 2, pp. 69-72, 2009.

[39] T. H. Oh and S. C. Chua, "Energy efficiency and carbon trading potential in Malaysia," Renewable and Sustainable Energy Reviews, vol. 14, no. 7, pp. 2095-2103, 2010.

[40] A. Kuriqi, A. N. Pinheiro, A. Sordo-Ward, M. D. Bejarano, and L. Garrote, "Ecological impacts of run-ofriver hydropower plants-Current status and future prospects on the brink of energy transition," Renewable and Sustainable Energy Reviews, vol. 142, pp. 110833, 2021.

[41] A. Kuriqi, A. N. Pinheiro, A. Sordo-Ward, and L. Garrote, "Influence of hydrologically based environmental flow methods on flow alteration and energy production in a run-of-river hydropower plant," Journal of Cleaner Production, vol. 232, pp. 1028-1042, 2019.

[42] A. Kadier, M. S. Kalil, M. Pudukudy, H. A. Hasan, A. Mohamed, and A. A. Hamid, "Pico hydropower (PHP) development in Malaysia: potential, present status, barriers and future perspectives," Renewable and Sustainable Energy Reviews, vol. 81, pp. 2796-2805, 2018.

[43] M. Awang, M. A. Zulkanai, N. H. N. Nafrizon, M. A. A. Rahman, M. M. S. Syazwan, M. S. R. Abdul Rahman, M. K. Musa, N. Hamidon, and F. Yusop, "Pico-hydro system as an alternative energy generator," AIP Conference Proceedings 2374, 2021. 